\title{
Dynamics of upstream movements of the European eel Anguilla anguilla in an inland area of the River Meuse over the last 20 years
}

\author{
Billy Nzau Matondo • Michaël Ovidio
}

Received: 28 July 2015 / Accepted: 27 January 2016/Published online: 10 February 2016

C) Springer Science+Business Media Dordrecht 2016

\begin{abstract}
The dynamics of upstream movements of the yellow eel Anguilla anguilla were investigated at Lixhe on the Belgian River Meuse in an inland fish pass regularly monitored from 1992 to 2014. Based on a constant year-to-year sampling effort, we examined the abundance of ascending yellow eels and their body size, seasonal movement, and the associated water temperature and flow. Over the last 23 years, the number of ascending yellow eels has declined at an average $4.2 \%$ per year since 1992. The abundance of eels in 2014 is estimated at $4.5 \%$ of the ascending stock in 1992 . We observed that some annual variations in eel abundance at Lixhe might be related to opening fish passes downstream of the study site. The results clearly demonstrated that long-term declining abundance of eels has resulted in increased sizes (mean increase, $4.1 \mathrm{~mm}$ per year since 1992 ) and temperatures triggering the upstream movement process $\left(1.03{ }^{\circ} \mathrm{C}\right.$ per decade), with earlier dates for the last eel passages reducing the difference between temperature extremes of eel passages through the fish pass during the migration season. Eel movements occurred in spring and summer at low river discharge and were mainly triggered by high-temperature events. Eels have become larger with time because of improved feeding opportunities and more growth habitats available resulting from the long-term reduction in recruitment. This study
\end{abstract}

B. N. Matondo $(\bowtie) \cdot$ M. Ovidio

Department of Biology, Ecology and Evolution, Applied and Fundamental Fish Research Center. Biology of Behaviour Unit, Laboratory of Fish Demography and Hydroecology, University of Liège, 22 Quai E. Van Beneden, B-4020 Liège, Belgium e-mail: bnmatondo@ulg.ac.be highlights the importance of investigating long time spans for a better comprehension of the changes observed in yellow eels and for the optimization of management measures and future research.

Keywords Abundance · Season · Migration · Yellow eel Freshwater

\section{Introduction}

Since the 1970s, eels have been in decline at all life stages throughout the entire European continental range (Naismith and Knights 1988; Moriarty 1990; ICES 2013), and since 2008 the species has been listed on the IUCN Red List as critically endangered (Jacoby and Gollock 2014). The hierarchy of the causes of the eel reduction remains unclear and this decline is observed at all developmental stages. However, the interaction of anthropogenic and environmental factors in both the riverine and ocean phases might explain this decline (Dekker 2003; Knights 2003; Bonhommeau et al. 2009).

The life cycle of the eel is complex and long. It includes reproduction in the Sargasso Sea and feeding and growth in various habitats ranging from seawater to freshwater where glass eels became elvers and then yellow eels before maturing into silver eels (Tesch 2003; van Ginneken and Maes 2005; Laffaille et al. 2006). The glass eel stage, which is a colonization phase near the estuary, remains the best documented, with sufficient historical recruitment data (ICES 2013). In 
contrast, the yellow eel stage, a growth phase with a highly sedentary lifestyle, covers most of the eel's freshwater life, but it has been less extensively studied (Baras et al. 1998; Ovidio et al. 2013). At this stage, some individuals continue to move towards upstream parts of inland waters and others stay in the lower part of the hydrographic network (Lobón-Cerviá et al. 1995; White and Knights 1997; Feunteun et al. 2003). In this context, it is difficult to understand, at inland sites, the effects of the long-term reduction in glass eel recruitment on the upstream movement process of the yellow eel stage. The initiation and cessation of annual upstream movements of eels in riverine systems is controlled by environmental variables such as water temperature and river discharge (Naismith and Knights 1988; Bark et al. 2007; Nzau Matondo et al. 2014). As a consequence, fish pass monitoring may play an important role by providing useful information on the upstream migration behavior of the riverine yellow eel (Welsh et al. 2015) in the context described above.

In the River Meuse, the Lixhe dam in Belgium, more than $300 \mathrm{~km}$ upstream from the North Sea, is the eighth major obstacle from the river mouth. This dam is equipped with a nonselective cone-trap pool retaining eels in a fish pass that has been scientifically and homogeneously monitored since 1992 . This long-term monitoring of the yellow eel stage is rare and unique, providing precise assessment of the changes in riverine yellow eel migration in inland waters. This knowledge may be useful in terms of eel management efforts at both the local and international levels.

Based on a constant year-to-year sampling effort since 1992, the present study aims to further summarize a 23-year monitoring program on the ascending migrant yellow eels through a fish pass built in the International River Meuse at Lixhe, Belgium. We examined whether the upstream movement dynamics of the riverine migrant yellow eels have changed over the years in terms of their abundance, body size, migration season, and catching temperature and flow.

\section{Methods}

Study site

The International Meuse River Basin drains a catchment area of $36,000 \mathrm{~km}^{2}$, of which $26 \%$ is situated in France, $2 \%$ in Luxembourg, $39 \%$ in Belgium, $11 \%$ in Germany, and $22 \%$ in the Netherlands. The river flows from France to the North Sea in the Netherlands with a total length of $925 \mathrm{~km}$ and has been regulated for hydropower generation and navigation. A total of $n=46$ obstacles obstructing fish migrations have been built on the main course of the River Meuse. From the river mouth in the Netherlands to our study site at Lixhe in Belgium, there are eight dams (the Netherlands: Lith, Grave, Sambeek, Belfeld, Roermond, Linne, and Borgharen; Belgium: Lixhe) including three hydropower stations (Lith, Linne, and Lixhe), which potentially influence the eels' upstream migration (Fig. 1). In the Dutch Meuse, dams were built in 1925-1936 and all were provided with Denil fish passes, which were gradually improved by the construction of new vertical-slot fish passes from 1989 to 1999, except Grave, where this new fish pass was installed in 2005 (Grave II) and Borgharen in 2007 (Borgharen II). In the Belgian Meuse at the Lixhe dam, two fish passes were opened; they include an old pooland-weir fish pass built in 1980 (Lixhe I) and a new vertical-slot fish pass in late 1998 (Lixhe II). Today the free movement of eels and other fish is ensured in the Meuse from its estuary to Lixhe. There are also tributaries and many canals and sluices associated with this river that offer different migration routes for eels.

This study was conducted in an inland part of the Meuse located at the Lixhe dam, where the river enters the Netherlands from Belgium, $323 \mathrm{~km}$ upstream from the North Sea on a non-navigable part of the river. It was built in 1980 and equipped on the right bank of the river with a 23,200-kW hydroelectric plant. Two multispecies vertical-slot fish passes ensure upstream passage for migrating fish. The Lixhe I fish pass, working at low discharge (maximum $0.3 \mathrm{~m}^{3} / \mathrm{s}$ ), is located between the hydroelectric plant and the spillway and equipped with a nonselective cone-trap pool retaining eels. This old fish pass has been regularly monitored since 1992 . In contrast, the Lixhe II fish pass was built for the migration of large fish species such as Atlantic salmon Salmon salar and sea trout Salmo trutta trutta, which operates at high flow $\left(1 \mathrm{~m}^{3} / \mathrm{s}\right)$ with larger pools and deeper slots. It is located on the right bank and equipped with a cage-trap selecting for large fish that does not retain eels.

Fig. 1 The location of the dams in the International River Meuse from the North Sea to Lixhe (a), the sampling site at the Lixhe dam in Belgium (b), the main hydraulic network of the Belgian River Meuse (c), and the old fish pass (d1) with eels trapped in its conetrap pool (d2) 

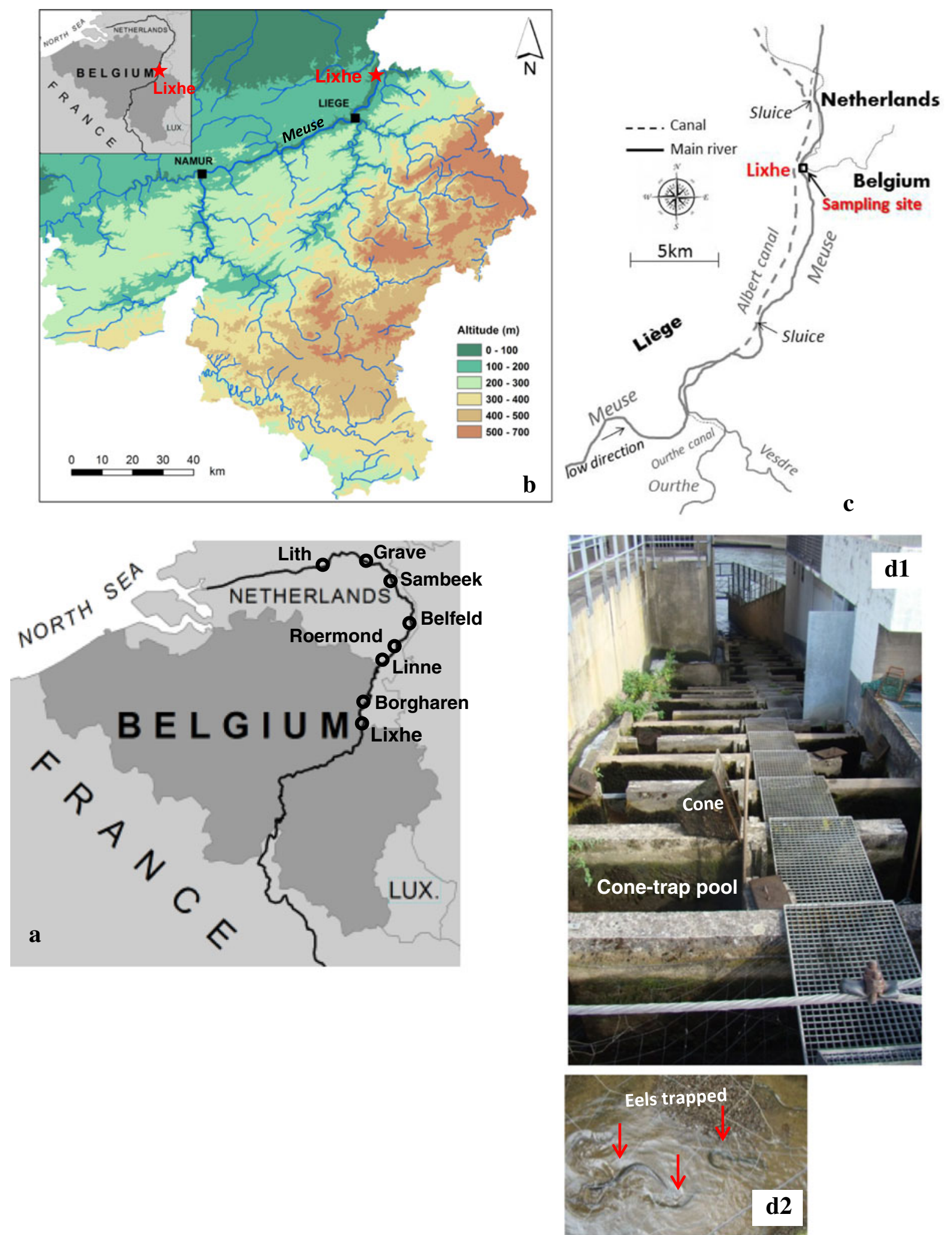
Upstream movements

From 1992 to 2014, yellow eels were caught exclusively in the old fish pass that retains eels with a cone-trap pool equipped with a steel grid with fine meshes preventing eels from leaving the upstream pool. Twice a week, the fish pass was monitored outside the main catch season and three times a week as soon as the first catch peak was observed during the catch season. The eels caught were anesthetized with eugenol $1 / 10$ in alcohol $(0.5 \mathrm{~mL} / \mathrm{L})$, counted, measured $( \pm 1 \mathrm{~mm})$, and weighed ( $\pm 1 \mathrm{~g})$.

The catch per unit effort (CPUE) was defined as the total number of eels caught daily. Declining levels of catches were determined by comparing the interannual catches throughout the entire time span (from 1992 to 2014). Similarly, the decline of eels was assessed in both time series before opening the second fish pass (19921998) and the time span that includes the new fish pass (1999-2014). The 1993 catch data were collected but they were not representative of the catch season because of the closure of the fish pass for renovation work during part of the eel migration season. This fish pass was again closed throughout 1994 and 1996 for improvements and therefore data were missing.

The lengths of the eels caught were analyzed annually by characterizing the mean and standard deviation as well as the minimum and maximum lengths.

To test the variations in the seasonal movements of the yellow eels through the old fish pass, each catch date was noted. The $5 \%$ eel passage dates and numbers of $5 \%$ of the eels, $50 \%$ (P50), $90 \%$, and $95 \%$ of the eels; the daily maximum number of eels; and the passage dates of first and last eels were described.

Considering the role of temperature and flow on catchability of the yellow eels in rivers and the small change observed in these environmental variables every three days each year during the sampling periods, each daily catch was associated with the daily temperature and flow of the Meuse since 1992. The water temperature was continuously recorded using temperature loggers $\left(\right.$ Onset $\left.{ }^{\circledR}\right)$. Flow data were provided by the Wallonia Public Service of Hydrological Studies (SETHY).

\section{Statistical analyses}

Variations in size, season, and temperature when the yellow eels moved upstream through the old fish pass were assessed over time and after the second fish pass was opened by performing a Kruskal-Wallis $(\mathrm{H})$ test followed by pairwise Mann-Whitney (U) post-hoc tests. Linear regression was run to test the relationships between the yearly catch of eels and time, between eel size and time, and between the CPUE, temperature and flow. A Generalized Linear Mixed Model (GLM) with backward stepwise elimination was used to investigate the relative influence of independent variables significantly related to the CPUE. The annual maximum daily catch was examined in terms of the distribution of eels per passage date between the summer and spring seasons and the temperature groups between $<20^{\circ} \mathrm{C}$ and $>20^{\circ} \mathrm{C}$ using the chi-square $\left(\chi^{2}\right)$ test. The $\chi^{2}$ test was also performed to check any significant difference in abundance between the two temperature groups cited for the catch of P50 eels. Statistical $P$-values less than 0.05 were treated as statistically significant. All statistical analyses were done using the statistical software package $\mathrm{R}$ version 3.1.2.

\section{Results}

Abundance and size of yellow eels

From 1992 to 2014, 37,626 yellow eels (biomass $2.43 \mathrm{t}$ ) measuring 14-88 cm were caught moving upstream through the old fish pass at Lixhe and the annual catch ranged from 208 to 5613 eels (Fig. 2a). The number of eels significantly decreased over time (1992-1998/ 1999-2014, before and after opening the new fish pass in late 1998: $\mathrm{R}^{2}=0.93 / 0.61, p=0.037 / 0.0003$ ), while their body size increased (minimum/mean lengths since $\left.1992, \mathrm{R}^{2}=0.22 / 0.77, p=0.031 /<0.00001\right)$. The CPUE varied annually (KW test, $\mathrm{df}=20 ; 814, \mathrm{H}=146.419$, $p<0.001$, U post-hoc test $p<0.01$ ), becoming significantly lower after 2003, except in 2008 (Table 1). During the 23-year monitoring period, four prominent peaks in terms of eel abundance were observed in 1992, 1995, 1999, and 2008 despite the general decreasing trend, as shown by the annual maximum CPUE, which ranged from 45 to 1335 eels. Similarly, a sudden drop in 2004 was detected just 1 year earlier with high numbers of eels (Fig. 2b). The level of eel decline occurred both before (1992-1998, decline rate nearly $7.8 \%$ per year) and after (1999-2014, $5.9 \%$ per year) the new fish pass opened. No sudden decline in the number of ascending eels was observed in the early years after the opening of the new fish pass. Since 1992, the number of eels in the old fish pass has declined by an approximate average of $4.2 \%$ 
Fig. 2 Year-to-year variations in the catch (a), relation between the daily maximum catch, date, water temperature, and flow (b), and the annual variation in body length (c) in the yellow eels migrating upstream through the old fish pass at the Lixhe in the River Meuse from 1992 to 2014. Mean, standard deviation, and range values for yellow eel length. * $P<0.05$, Kruskal-Wallis and Mann-Whitney tests for eel length. Data from 1993 are not representative of the catch season. Year of opening the new fish pass during the study period at the sampling site in Belgium (Lixhe II) and the lower part of the River Meuse in the Netherlands (Grave II and Borgharen II)
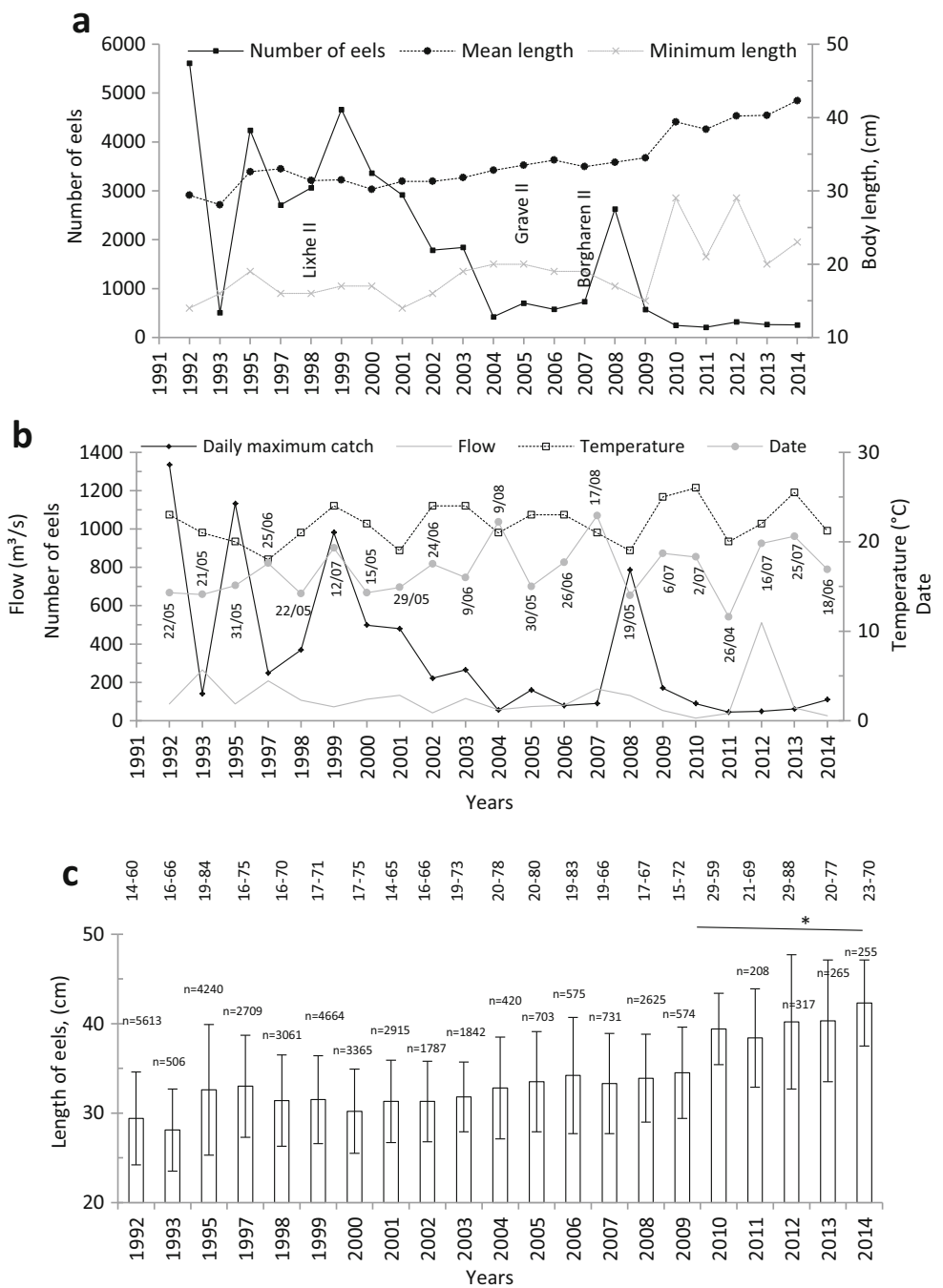

per year. After the opening of the new fish pass (19992014), the highest annual maximum CPUE occurred in both 1999 ( $n=981$ eels per day) and 2008 (786 eels per day) while before opening the fish pass (1992-1998), it was observed in $1992(n=1335$ eels per day) and 1995 ( $n=1132$ eels per day). The yearly maximum CPUE dropped by approximately $12.1 \%$ per year before opening the new fish pass versus $5.6 \%$ thereafter.

The body length of the yellow eels moving upstream through the old fish pass differed annually (KW test, df $=2 ; 37180, \mathrm{H}=1383.06, p<0.001)$ and was significantly higher (U post-hoc test $p<0.05$ ) during the 2010s (annual mean range, 38-42 cm) than in the 2000s (30-35 cm) and the 1990s (28-33 cm) (Fig. 2c).
Since 1992 the mean and minimum eel length increased by approximately 0.41 and $0.56 \mathrm{~cm}$ per year, respectively.

\section{Migration season}

Yellow eels moved upstream through the old fish pass between 3 April and 23 October, with $90 \%$ of the eels from 22 April to 7 September, P50 eels from 6 May to 29 July, and the annual daily peak of eels from 26 April to 17 August. The maximum seasonal duration of eel movements ranged from 90 to 193 days, with $90 \%$ of the eels passing within a period lasting from 40 to 129 days. 
Table 1 Year-to-year values of the catch and periodicity of the yellow eel moving upstream through the old fish pass at the Lixhe in the River Meuse from 1992 to 2014

\begin{tabular}{|c|c|c|c|c|c|c|c|}
\hline \multirow[t]{2}{*}{ Decades } & \multirow[t]{2}{*}{ Years } & \multirow[b]{2}{*}{ Total number } & \multicolumn{2}{|l|}{ CPUE } & \multicolumn{3}{|c|}{ Catch period } \\
\hline & & & Mean & $\mathrm{SD}$ & $P 50$ & $90 \%$ (days) & $100 \%$ (days) \\
\hline \multirow[t]{6}{*}{$1990 \mathrm{~s}$} & 1992 & 5613 & 152 & 286 & 25 May & 11 May-24 Jun (44 d) & 30 Apr-7 Sep (130 d) \\
\hline & $1993^{\mathrm{a}}$ & 506 & 12 & 23 & 21 May & 30 Apr-7 Jul (68 d) & 14 Apr-18 Sep (157 d) \\
\hline & 1995 & 4240 & 118 & 251 & 31 May & 26 May-5 Jul (40 d) & 3 May-6 Oct (156 d) \\
\hline & 1997 & 2709 & 55 & 57 & 25 Jun & 16 May-18Aug (94 d) & 4 Apr-15 Sep (164 d) \\
\hline & 1998 & 3061 & 73 & 95 & 8 Jun & 18 May-7 Sep (112 d) & 4 May-5 Oct (154 d) \\
\hline & 1999 & 4664 & 68 & 170 & $12 \mathrm{Jul}$ & 15 May-6 Aug (83 d) & 19 Apr-10 Oct (174 d) \\
\hline \multirow[t]{10}{*}{2000 s } & 2000 & 3365 & 80 & 106 & 5 Jun & 8 May-20 Jul (73 d) & 24 Apr-29 Sep (158 d) \\
\hline & 2001 & 2915 & 85 & 115 & 29 May & 11 May-28 Aug (109 d) & 30 Apr-1 Oct (154 d) \\
\hline & 2002 & 1787 & 40 & 49 & 7 Jun & 6 May-5 Aug (91 d) & 5 Apr-17 Sep (165d) \\
\hline & 2003 & 1842 & 43 & 58 & 11 Jun & 30 Apr-18 July (79 d) & 3 Apr-27 Aug (146 d) \\
\hline & 2004 & 423 & 11 & 14 & $29 \mathrm{Jul}$ & 3 May-23 Aug (112 d) & 23 Apr-1 Oct (161 d) \\
\hline & 2005 & 703 & 18 & 30 & 24 Jun & 6 May-25 Jul (80 d) & 4 Apr-30 Sep (179 d) \\
\hline & 2006 & 575 & 16 & 19 & 26 Jun & 12May-27Jul (76 d) & 24 Apr-31 Aug (129d) \\
\hline & 2007 & 731 & 13 & 20 & 18 Jun & 23 Apr-30Aug (129 d) & 13 Apr-23 Oct (193 d) \\
\hline & 2008 & 2625 & 49 & 113 & 19 May & 9 May-14 Jul (66 d) & 23 Apr-15 Oct (175 d) \\
\hline & 2009 & 574 & 17 & 38 & $3 \mathrm{Jul}$ & 27 May-20 Jul (54 d) & 17 Apr-17 Sep (153d) \\
\hline \multirow[t]{5}{*}{$2010 \mathrm{~s}$} & 2010 & 248 & 15 & 21 & $2 \mathrm{Jul}$ & 26 May-19 Jul (54 d) & 29 Apr-28 Jul (90 d) \\
\hline & 2011 & 208 & 6 & 8 & 6 May & 22 Apr-19 Jul (88 d) & 22 Apr-10 Oct (171 d) \\
\hline & 2012 & 317 & 12 & 17 & 21 Jun & 11 May-23 Aug (104 d) & 11 May-10 Sep (122 d) \\
\hline & 2013 & 265 & 9 & 15 & $25 \mathrm{Jul}$ & 10 jun-1 Aug (52 d) & 25 Apr-13 Sep (141 d) \\
\hline & 2014 & 255 & 13 & 24 & 18 jun & 30 May-25 Jul (56 d) & 26 May-25 Aug (91 d) \\
\hline
\end{tabular}

${ }^{a}$ Data are not representative of the catch season. P50 specifies the median values. SD indicates the standard deviation. 1992 the beginning regular year-to-year sampling in the first (old) fish pass at Lixhe dam, and 1999 the first eel migration season after opening the second (new) fish pass in late 1998 on the same site

None of these descriptors of eel movement dates significantly changed over time or with the opening of the new fish pass (KW test, $p>0.05$ ). Similarly, the movement dates have not significantly changed over time for the passage dates of the first eels and $5 \%$ and $95 \%$ of the eels. Contrary to the first eels, the passage dates of the last eels occurred significantly earlier over time. They passed earlier during the 2010s (mean \pm SD: 19 August \pm 25 days) than in the 2000s (25 September \pm 18 days) and the 1990s (27 September \pm 15 days) (KW test, $\mathrm{df}=2 ; 19$, $\mathrm{H}=7.927, p=0.019$, $\mathrm{U}$ post-hoc test $p<0.05)$. The daily maximum number of eel passages was observed annually in summer (from 9 June to 17 August: $57.1 \%$ of the 21 years examined) as well as during the spring (26 April to 30 May: $42.9 \%$; $\chi^{2}=0.86 ; p=0.345$ ).
Temperature and flow at capture

Each year the eel catch started with the river warming, increased as the temperature rose, and dropped as the river cooled (Fig. 3). The eel catch occurred mainly at low river discharge. Yellow eels were caught at water temperatures ranging from 10.5 (one eel on 16 April 1999) to $29.1{ }^{\circ} \mathrm{C}$ (99 eels on 28 July 1995) and flow between 6.2 (nine eels on 31 July 1995) and $651.8 \mathrm{~m}^{3} / \mathrm{s}$ (12 eels on 29 May 2006) (Fig. 4). The catch temperature and flow showed significant annual variations (KW test, $\mathrm{df}=20 ; 37,204, \mathrm{H}=340.962$, $p<0.0001$ and $\mathrm{H}=3871.057, p<0.0001$, respectively), with higher catch temperature $\left(P 50: 21.6{ }^{\circ} \mathrm{C}\right.$, $\mathrm{U}$ post-hoc test $p<0.0001)$ and lower catch flow (P50: $51.8 \mathrm{~m}^{3} / \mathrm{s}$, U post-hoc test $p<0.01$ ) during the 
a
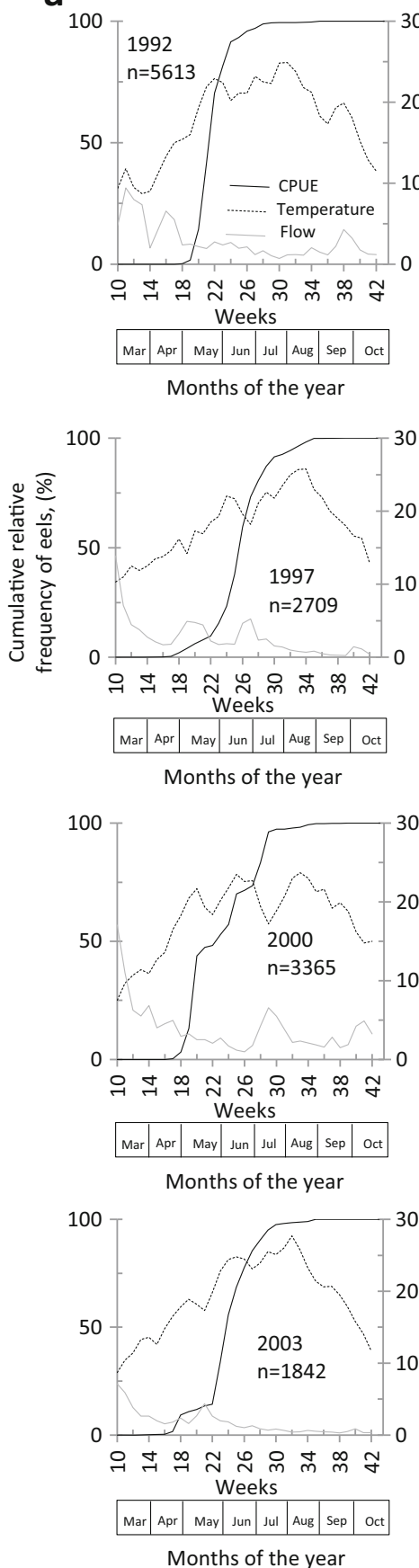
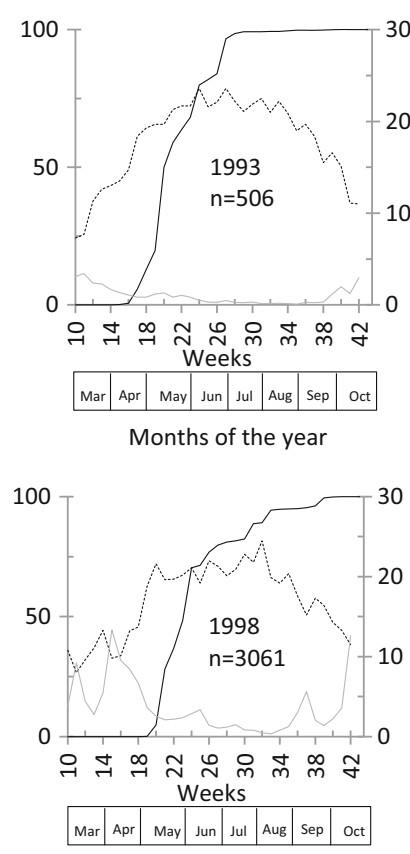

Months of the year

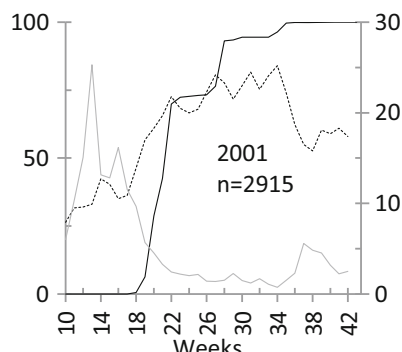

의 $\triangleleft \stackrel{\infty}{\sim} \underset{\text { Weeks }}{\mathbb{N}}$

$$
\begin{array}{|l|l|l|l|l|l|l|}
\hline \text { Mar } & \text { Apr } & \text { May } & \text { Jun } & \text { Jul } & \text { Auz } & \text { Sep } \\
\hline
\end{array}
$$

Months of the year

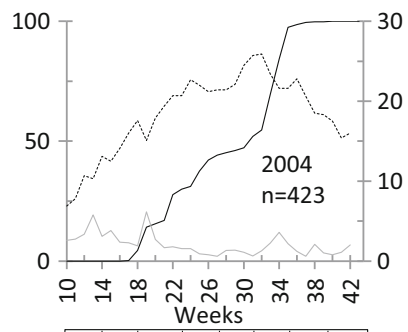

$$
\begin{array}{|l|l|l|l|l|l|l|l|}
\hline \text { Mar } & \text { Apr } & \text { May } & \text { Jun } & \text { Jul } & \text { Aug } & \text { Sep } & \text { Oct } \\
\hline
\end{array}
$$

Months of the year


Months of the year

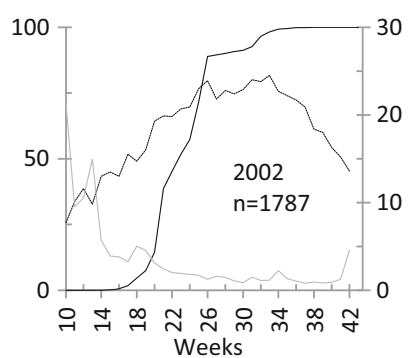

\begin{tabular}{|l|l|l|l|l|l|l|l|}
\hline Mar & Apr & May & Jun & Jul & Aug & Sep & Oct \\
\hline
\end{tabular}

Months of the year

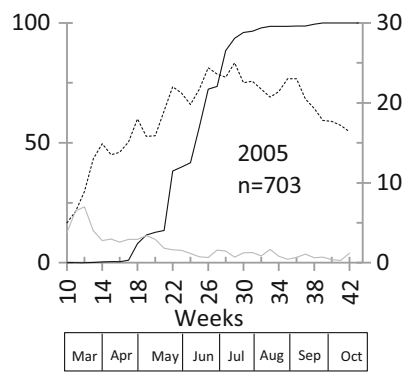

Months of the year

Fig. 3 a \& b Relation between the cumulative catch per unit effort (CPUE) of the yellow eels, the week of the year, the water temperature, and the flow of the Belgian River Meuse at the Lixhe dam from 1992 to 2014. CPUE data in1993 are not representative of the catch season

2010s. Relationships between CPUE, water temperature, and flow showed annual variations with sometimes the CPUE correlating significantly with temperature or flow (Table 2). While CPUE in 2006 was significantly correlated with both temperature and flow, temperature was a better predictor of CPUE (GLM, F 2; $36=5.7122$, 
b
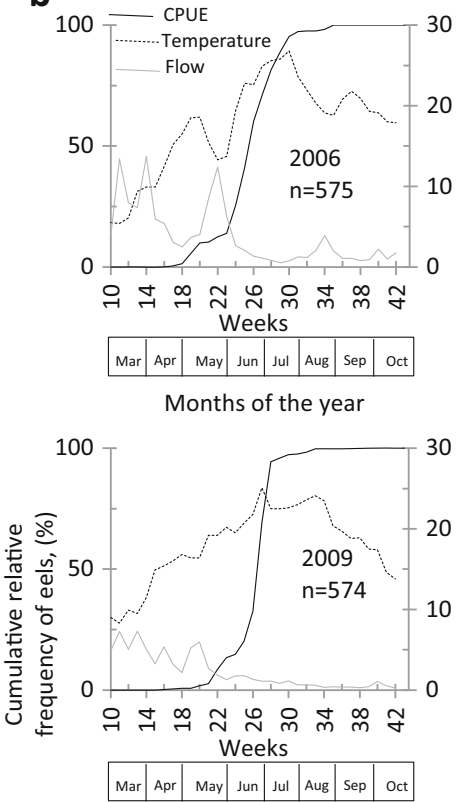

Months of the year

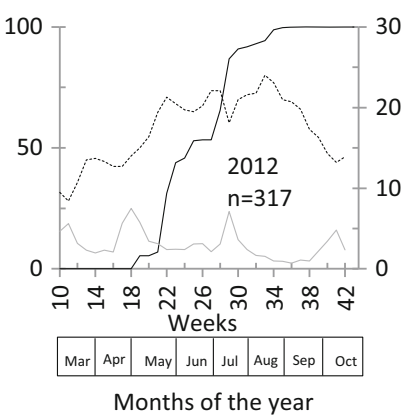

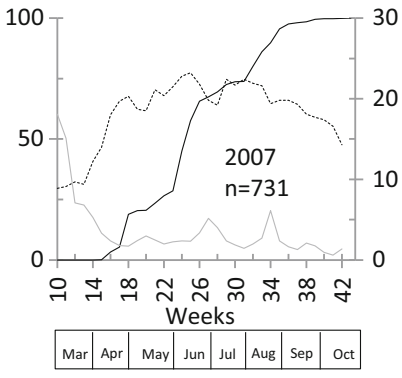

Months of the year

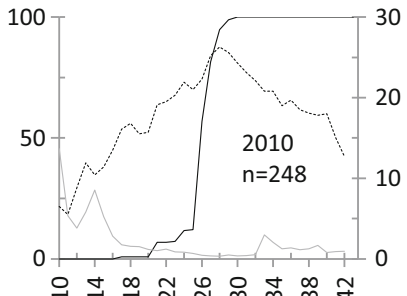


\begin{tabular}{|l|l|l|l|l|l|l|l|}
\hline Mar & Apr & May & Jun & Jul & Aug & Sep & Oct \\
\hline
\end{tabular} Months of the year

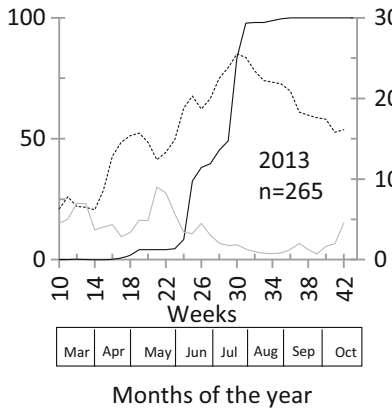



Months of the year

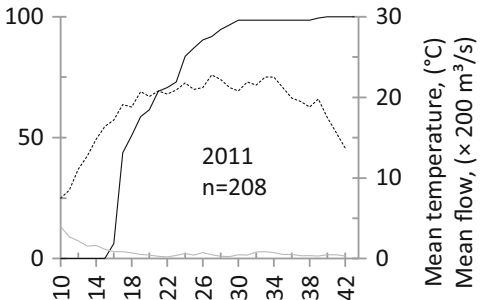

Weeks



Months of the year

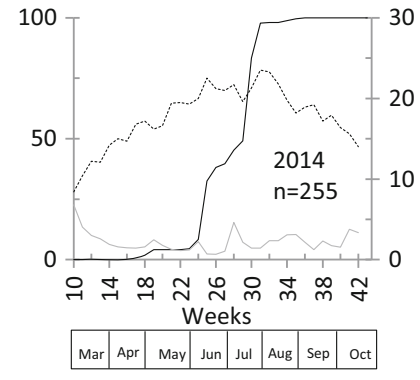

Months of the year

Fig. 3 (continued)

$p=0.0074)$ over flow $(p=0.6351)$ with elevated temperature resulting in higher CPUE and explaining $25.2 \%$ of the variation in CPUE. The relative independence of temperature and flow in years without correlations with CPUE was substantiated by both higher median temperature $\left(19.8-23.9{ }^{\circ} \mathrm{C}\right)$ and thermal axis $\left(15-26.3{ }^{\circ} \mathrm{C}\right)$ for $90 \%$ of the eels caught, and both lower median flow $\left(16.1-130.7 \mathrm{~m}^{3} / \mathrm{s}\right)$ and flow axis $\left(10.1-343.8 \mathrm{~m}^{3} / \mathrm{s}\right)$ for $90 \%$ of the eels.

Minimum temperatures for eel migratory activity have increased over time by approximately $1.03{ }^{\circ} \mathrm{C}$ per decade since 1992, and were significantly higher during the 2010s (mean \pm SD: $16.5 \pm 1.1{ }^{\circ} \mathrm{C}$ ) than in the 1990s $\left(13.4 \pm 1.4{ }^{\circ} \mathrm{C}\right)$ and the $2000 \mathrm{~s}\left(13.7 \pm 1.1^{\circ} \mathrm{C}\right)(\mathrm{KW}$ test, $\mathrm{df}=2 ; 20, \mathrm{H}=7.498, p=0.023$, $\mathrm{U}$ post-hoc test $p<0.05$ ). The maximum CPUE mainly occurred at $>20{ }^{\circ} \mathrm{C}$ for $76 \%$ of the 21 years and $<170 \mathrm{~m}^{3} / \mathrm{s}$ for $86 \%\left(\chi^{2}=11.52\right.$, $p=0.0007$ and $\chi^{2}=21.43 ; p=0.0001$, respectively). Concomitantly with increasing the minimum temperature, the differences between the extreme values of the temperature for $100 \%$ of the eel passages have decreased over time by nearly $1.2{ }^{\circ} \mathrm{C}$ per decade since 1992 and were significantly lower during the $2010 \mathrm{~s}\left(8.9 \pm 1.6^{\circ} \mathrm{C}\right)$ than in the 2000s $\left(11.4 \pm 1.5^{\circ} \mathrm{C}\right)$ and the $1990 \mathrm{~s}\left(12.6 \pm 1.8^{\circ} \mathrm{C}\right)$ (KW test, $\mathrm{df}=2.20, \mathrm{H}=6.631, p=0.036$; $\mathrm{U}$ post-hoc test $p<0.05)$. However, neither time nor the opening of the new fish pass significantly affected the temperatures on the dates when $5 \%$ and $95 \%$ of the eel passages had occurred, when the last eel had passed, the daily peak in the number of eels, and the difference in temperature extremes of the times when $90 \%$ of the eels had passed (KW test, $p>0.05$ ). 
Fig. 4 a River temperature and (b) flow at the catch of the yellow eels moving upstream through the old fish pass at the Lixhe in the River Meuse from 1992 to 2014. Data from 1993 are not representative of the catch season. Values are median and 5th, 25th, 75 th, and 95 th percentiles. The bar inside the box marks the position of the median that overlaps with the 25 th percentiles in 1995 for temperature and 2012 and 2014 for flow and the 75th percentile in 2010 and 2014 for temperature. Open circles indicate outliers


\section{Discussion}

In this study based on a constant year-to-year sampling effort, the abundance of the riverine yellow eels migrating upstream through a fish pass showed a significant decreasing trend beginning in 1992, indicating a drop in production of silver eels over the long term and therefore low local contributions to the panmictic spawning stock. This decline also reflects the reality of the decline of the species reported in all developmental stages throughout its geographic range (Bonhommeau et al. 2008; ICES 2013; MacNamara and McCarthy 2014; 
Table 2 Relationships between CPUE, river temperature, and flow of the yellow eel moving upstream through the old fish pass at the Lixhe in the River Meuse from 1992 to 2014

\begin{tabular}{|c|c|c|c|c|}
\hline \multirow[b]{2}{*}{ Decades } & \multirow[b]{2}{*}{ Years } & \multirow[b]{2}{*}{$\begin{array}{l}\text { Number of } \\
\text { catch days }\end{array}$} & \multicolumn{2}{|c|}{$\begin{array}{l}\mathrm{R}^{2} \text { values of the relationships } \\
\text { between }\end{array}$} \\
\hline & & & $\begin{array}{l}\text { CPUE and } \\
\text { temperature }\end{array}$ & $\begin{array}{l}\text { CPUE and } \\
\text { flow }\end{array}$ \\
\hline \multirow[t]{6}{*}{$1990 \mathrm{~s}$} & 1992 & 37 & 0.0109 & 0.0017 \\
\hline & $1993^{\mathrm{a}}$ & 41 & 0.0086 & $0.1329 *$ \\
\hline & 1995 & 36 & 0.0047 & 0.0488 \\
\hline & 1997 & 48 & $0.0965^{*}$ & 0.072 \\
\hline & 1998 & 42 & $0.1068^{*}$ & 0.0039 \\
\hline & 1999 & 63 & 0.0426 & 0.0241 \\
\hline \multirow[t]{10}{*}{$2000 \mathrm{~s}$} & 2000 & 42 & 0.0208 & 0.0022 \\
\hline & 2001 & 34 & 0.038 & 0.0125 \\
\hline & 2002 & 45 & 0.042 & $0.155^{* *}$ \\
\hline & 2003 & 43 & $0.1655^{* *}$ & 0.001 \\
\hline & 2004 & 38 & $0.1336^{*}$ & 0.0202 \\
\hline & 2005 & 42 & $0.1747 * *$ & 0.0474 \\
\hline & 2006 & 36 & $0.252 * *$ & $0.1115^{*}$ \\
\hline & 2007 & 49 & $0.1606^{* *}$ & 0.0126 \\
\hline & 2008 & 54 & 0.0012 & 0.0249 \\
\hline & 2009 & 36 & $0.2651^{* *}$ & 0.0151 \\
\hline \multirow[t]{5}{*}{$2010 \mathrm{~s}$} & 2010 & 17 & 0.1212 & 0.1031 \\
\hline & 2011 & 36 & 0.0496 & $0.1365^{*}$ \\
\hline & 2012 & 27 & 0.046 & 0.2153 \\
\hline & 2013 & 28 & $0.1431 *$ & 0.001 \\
\hline & 2014 & 20 & 0.0014 & 0.1475 \\
\hline
\end{tabular}

${ }^{\text {a }}$ Data are not representative of the catch season

Levels of significance* $p<0.05, * * p<0.001,{ }^{* * *} p<0.0001$

Hanel et al. 2014). However, in the present study, the decline of the riverine yellow eel stage in inland water (at Lixhe, mean decline of $4.2 \%$ per year beginning in 1992 in a 23-year study) appears lower than that of the estuarine eels (Bridgwater Bay $15 \%$ per year beginning in 1980 in a 30-year study; Henderson et al. 2012). Abundance of the yellow eels at the Belgian border with the Netherlands in 2014 is estimated at $4.5 \%$ of the number of eels in 1992 versus only $1 \%$ of the abundance in 1980 in Bridgwater Bay in 2009, which is one of the sharpest quantified drops reported in the eel population. Estuaries are areas with high potential eel density, predominated by males staying in rivers for a shorter period of time prior to migrating downstream to spawning grounds (Ibbotson et al. 2002). Contrary to estuaries, riverine inland environments such as our sampling site are potentially predominated by female eels that live for long periods in rivers. The difference between these two decreasing rates of the eel population could be due to study area locations and time spans.

The sudden annual increase of eels that was observed in 2008 might also stem from the new fish passes opened at the Borgharen-Maastricht weir (December 2007) near Lixhe and the Grave weir (in 2005) near the estuary in the Dutch Meuse (Belpaire et al. 2014) downstream on the Belgian Meuse. The annual increase in 1999 may be attributed to the same cause, i.e., the effect of opening a second passageway for ascending fish at the Lixhe dam, which increased the availability of the upstream migration route of the River Meuse at Lixhe, thus reducing use of the Albert canal. However, the role played by this second fishway, which does not have a trap for eels, as well as the alternative migration routes such as the Albert canal on the upstream migratory flux of eels need to be further elucidated. The reopening of the old fish pass at the Lixhe dam after its closure during part of 1993 and all of 1994 could also explain the eel catch increase in 1995 due to reopening the passage for eels blocked downstream. The four prominent annual eel increases with their higher maximum daily catch at Lixhe matched the higher glass eel recruitments observed 1-2 years earlier in the North Sea (Belpaire et al. 2014). The sudden drop in 2004 also matched lower levels of glass eel recruitments for three consecutive years (2001-2003) never observed before 2004 in the North Sea. Similarly, the drop in 2004 observed before the opening of the Grave weir in 2005 and the peak catch in 2008 after the opening of Borgharen weir may indicate that the construction and renovation works downstream of the River Meuse may have impacted the lower number of ascending eels recorded at Lixhe between 2004 and 2007. These observations demonstrate that, during the general decline trend, the upstream flux of migrant yellow eels farther from the sea may have balanced on the longitudinal axis, with the opening of both the fish pass and alternative migration routes (canals, locks, and gates in part of the dam) and the improving youth recruitment stages caused by the density dependence effect (Briand et al. 2005). According to Feunteun et al. (2003), the movement pattern of riverine eels, as at our sampling site, 
may operate between both the new incoming eels belonging to early eel stages and the older individuals that had been present in the river for several years, thereby influencing the eel capture in the fish pass at Lixhe.

Concomitant with a gradual decline in yellow eel abundance, the size of eels increased significantly in terms of both mean and minimum length. This change in eel size and range clearly indicates that the population collapse in this study may have been caused by a recruitment failure for which the reason remains unidentified. It is suggested that both unfavorable environmental and anthropogenic factors acting at different stages in the eel life cycle may have been involved in this demographic regression. With the recruitment decline, eels may remain downstream in the Meuse due to increased habitat availability, less competition, and improved feeding opportunities. Because of the increasing size of migrant yellow eels, aging eels with a biased sex ratio in favor of females have probably been involved in upstream migration, especially since adult males are $37-45 \mathrm{~cm}$ in length at silvering and seaward migration, whereas females' total length is greater than $45 \mathrm{~cm}$ (De Leo and Gatto 1995; MacNamara and McCarthy 2014). Given the strong positive relationship between size and fecundity in female eels, increasing size may have compensated decreasing recruitment as females must maximize growth to ensure a better cohort (Jellyman 2001). Like panmictic and semelparous species (Van Ginneken and Maes 2005; Als et al. 2011), a gradual decline in recruitment indicates a risk of losing eels at the local level and therefore at the international level, a real extinction threat to the species because of a lack of a meta-population structure (Hanski 1998). Particularly in the River Meuse, the upstream habitats are no longer colonized by eels and will therefore be emptied of this fish species when the last resident eels migrate to spawn. In this context, eel conservation actions such as well-targeted glass eel stocking to enhance yellow eel abundance may be necessary conservation measures, if adequately carried out (Ovidio et al. 2015; Brämick et al. 2015).

Observation of a similar migration season of riverine yellow eels based on long-term sampling (over a 23year study beginning in 1992) at Lixhe suggests that eels have not significantly changed their migration behaviors over the years. This raised the hypothesis that a precise mechanism linking the migration period and upstream movement in eels may be controlled by an external stimulus, in particular higher water temperature during spring and summer (Moriarty 1986; Naismith and Knights 1988), and population parameters determining density-dependent movements associated with certain endogenous rhythms (Castonguay et al. 1990; Feunteun et al. 2003; Edeline et al. 2009). Similarly, the migration season reported in this study was typical of the anguillid eel population at this life stage (Tesch 2003). However, a long-term reduction in eel recruitment has resulted in early passage dates of the last eels during the migration seasons in inland areas.

With the median and maximum daily eel catch mostly observed at $>20^{\circ} \mathrm{C}$ and the daily catch by almost 100 eels at $29.1{ }^{\circ} \mathrm{C}$, these results clearly confirm that eels preferred high temperatures for migratory activity. Similarly, the minimum temperature increase observed may be interpreted as shifts in minimum temperature limits required for migratory activity toward higher temperatures. White and Knights (1997) and Naismith and Knights (1988) reported the accepted limits of 10$15^{\circ} \mathrm{C}$ in eels for the beginning of migration, which were lower than the limits of $14-18^{\circ} \mathrm{C}$ observed in this recent decade in our study. White and Knights (1997) observed that the eel catches peaked at $21-22^{\circ} \mathrm{C}$. In our study, the daily catch of eels mainly occurred at low discharge and started with the river warming, increased with rising temperature, and dropped as the river cooled. This showed that water temperature over river flow was a crucial factor triggering, stimulating, and controlling the movements of yellow eels in the Meuse. Furthermore, the combined action of minimum temperature increase to start the migration process in addition to the early end of migration explains why the difference in temperature extremes for $100 \%$ eel passages have been decreasing over time (nearly $1.2{ }^{\circ} \mathrm{C}$ per decade since 1992). The maximum daily catch of yellow eels occurred in summer as well as in spring when the water temperature was favorable to migratory activity. In a Cantabrian river in Spain, Lobón-Cerviá et al. (1995) observed that eel numbers increased in spring and summer and peaked in late autumn, coincident with higher water temperature. The migration of some yellow eels in early spring and late autumn recorded in this study was again explained by temperatures favorable to migration (Naismith and Knights 1988; White and Knights 1997). On the other hand, the knowledge gained on the precise migration dates of the yellow eels can be very helpful in eel conservation actions such as seasonal maintenance of 
fish passes and other eel migration routes, timing and duration of eel trapping, as well as hydroelectricity production. These long-term data can also facilitate improved fish passage and access to upstream habitats on large river systems.

This study provides insight into the main changes observed in the riverine migrant yellow eels in a long-term declining abundance trend and highlights the importance of studying long-term time spans for a better comprehension of yellow eel population changes and for optimizing management measures. These results clearly indicate that the reduction in recruitment over the years led to both increased eel size and higher minimum temperatures for migration. They also confirm that the eel decline caused an earlier onset of the last eel passages in the migration season, therefore reducing the differences in temperature extremes between the passages of the first and last eels. In this context, it would be relevant and urgent to elucidate the age, sex, and life history of the yellow eels migrating farther from the sea.

Acknowledgments The authors express their thanks to J.C. Philippart who provided historical catch data and SETHY-MET of Wallonia Public Service (SPW) for the environmental data. We also thank G. Rimbaud, A. Dierckx, and J.P. Benitez for their participation in the fieldwork and anonymous referees for their valuable comments on this manuscript. This study was funded by the "Stock abundance estimation of wild yellow eels recruited by upstream migration in the Meuse River of Wallonia and implementation of restocking tests using glass eels and elvers" project funded by the European Fisheries Fund (FEP No. 32-1102-002) and represented by X. Rollin and F. Fontaine.

\section{References}

Als TD, Hansen MM, Maes GE, Castonguay M, Riemann L, Aarestrup K, Munk P, Sparholt H, Hanel R, Bernatchez L (2011) All roads lead to home: panmixia of European eel in the Sargasso Sea. Mol Ecol 20:1333-1346. doi:10.1111/j.1365294X.2011.05011.x

Baras E, Jeandrain D, Serouge B, Philippart JC (1998) Seasonal variations in time and space utilization by radio-tagged yellow eels Anguilla anguilla (L.) in a small stream. Hydrobiologia 371(372):187-198. doi:10.1023/A:1017072213791

Bark A, Williams B, Knights B (2007) Current status and temporal trends in stocks of European eel in England and Wales. ICES J Mar Sci 64:1368-1378. doi:10.1093/icesjms/fsm117

Belpaire C, Buysse D, Breine J, Verreycken H, Ovidio M, Nzau Matondo B, Meyer JD, Adrianes D, Roland K, Kestemont P, Rollin X, Vlietinck K (2014) Report on the eel stock and fishery in Belgium 2013/2014. In Joint EIFAAC/ICES/
GFCM WGEEL Report. pp. 202-244. http://hdl.handle.net/ 1854/LU-5826651

Bonhommeau S, Chassot E, Rivot E (2008) Fluctuations in European eel (Anguilla anguilla) recruitment resulting from environmental changes in the Sargasso Sea. Fish Oceanogr 17:32-44. doi:10.1111/j.1365-2419.2007.00453.x

Bonhommeau S, Le Pape O, Gascuel D, Blanke B, Treguier AM, Grima N, Vermard Y, Castonguay M, Rivot E (2009) Estimates of the mortality and the duration of the transAtlantic migration of European eel Anguilla anguilla leptocephali using a particle tracking model. J Fish Biol 74:18911914. doi:10.1111/j.1095-8649.2009.02298.x

Brämick U, Fladung E, Simon J (2015) Stocking is essential to meet the silver eel escapement target in a river system with currently low natural recruitment. ICES J Mar Sci. doi:10. 1093/icesjms/fsv113

Briand C, Fatin D, Fontenelle G, Feunteun E (2005) Effect of reopening of a migratory pathway for eel (Anguilla anguilla, L.) at a watershed scale. Bull Fr Pêche Piscic 378-379:6786. doi:10.1051/kmae:2005004

Castonguay M, Dutil JD, Audet C, Miller R (1990) Locomotor activity and concentration of thyroid hormones in migratory and sedentary juvenile American eels. T Am Fish Soc 119:946956. doi:10.1577/1548-8659(1990)119<0946:LAACOT>2.3. $\mathrm{CO} ; 2$

De Leo GA, Gatto M (1995) A size and age-structured model of the European eel (Anguilla anguilla L.). Can J Fish Aquat Sci 52:1351-1367. doi:10.1139/f95-131

Dekker W (2003) Did lack of spawners cause the collapse of the European eel, Anguilla anguilla? Fish Manag Ecol 10:365376. doi:10.1111/j.1365-2400.2003.00352.x

Edeline E, Dufour S, Elie P (2009) Proximate and ultimate control of eel continental dispersal, chapter published in "Spawning Migration of the European Eel Reproduction Index, a Useful Tool for Conservation Management 433-461" doi:10.1007/ 978-1-4020-9095-0 18

Feunteun E, Lafaille P, Robinet T, Briand C, Baisez A, Olivier JM, Acou A (2003) A review of upstream migration and movements in inland waters by Anguillide els: toward a general theory. In: Aida K, Tsukamoto K, Yamauchi K (eds) Eel Biology. Springer-Verlag, Tokyo, pp. 1991-1213. doi:10. 1007/978-4-431-65907-5 14

Hanel R, Stepputtis D, Bonhommeau S, Castonguay M, Schaber M, Wysujack K, Vobach M (2014) Miller MJ (2014) Low larval abundance in the Sargasso Sea: new evidence about reduced recruitment of the Atlantic eels. Naturwissenschaften 101:1041-1054. doi:10.1007/s00114-014-1243-6

Hanski I (1998) Metapopulation dynamics. Nature 396:41-49 ICES. 2010. ICES Advice 2010, Book 9

Henderson PA, Plenty SJ, Newton LC, Bird DJ (2012) Evidence for a population collapse of European eel (Anguilla anguilla) in the Bristol Channel. J Mar Biol Assoc U K 92:843-851. doi:10.1017/S002531541100124X

Ibbotson A, Smith J, Scarlett P, Aprahamian MW (2002) Colonisation of freshwater habitats by the European eel Anguilla anguilla. Freshw Biol 47:1696-1706. doi:10. 1046/j.1365-2427.2002.00930.x

ICES (2013) Report of the Joint EIFAAC/ICES Working Group on Eels (WGEEL), 3-9 September 2012, Copenhagen, Denmark. ICES CM 2013/ACOM:18. 824224 pp 
Jacoby D, Gollock M (2014) Anguilla anguilla. In: IUCN 2014. IUCN Red List of Threatened Species Version 2014.1. $<$ www.iucnredlist.org >

Jellyman DJ (2001) The influence of growth rate on the size of migrating female eels in Lake Ellesmere, New Zealand. J Fish Biol 58:725-736. doi:10.1111/j.1095-8649.2001.tb00525.x

Knights B (2003) A review of the possible impacts of long-term oceanic and climate changes and fishing mortality on recruitment of anguillid eels of the Northern Hemisphere. Sci Total Environ 310:237-244

Laffaille P, Acou A, Legault A, Guillouët J, Mounaix B, Lek S (2006) Patterns of silver eel (Anguilla anguilla, L.) sex ratio in a catchment. Ecol Freshw Fish 15:583-588. doi:10.1111/j. 1600-0633.2006.00195.x

Lobón-Cerviá J, Utrilla CG, Rincón PA (1995) Variations in the population dynamics of the European eel Anguilla anguilla (L.) along the course of a Cantabrian river. Ecol Freshw Fish 4:17-27. doi:10.1111/j.1600-0633.1995.tb00023.x

MacNamara R, McCarthy TK (2014) Silver eel (Anguilla anguilla) population dynamics and production in the River Shannon, Ireland. Ecol Freshw Fish 23:181-192. doi:10. 1111/eff. 12028

Moriarty C (1986) Riverine migration of young eels Anguilla anguilla (L.). Fish Res 4:43-58. doi:10.1016/01657836(86)90027-5

Moriarty C (1990) European catches of elver of 1928-1988. Intern Revue Hydrobiol Hydrogr 75:701-706. doi:10.1002/iroh. 19900750603

Naismith IA, Knights B (1988) Migrations of elvers and juvenile European eels, Anguilla anguilla L., in the River Thames. J
Fish Biol 33:161-175. doi:10.1111/j.1095-8649.1988. tb05570.x

Nzau Matondo B, Philippart JC, Dierckx A, Benitez JP, Ovidio M (2014) Arrival of European eel in Belgian part of the Meuse: who and how are they? proceedings of the 10th international conference on ecohydraulics, Trondheim, Norway. http://hdl. handle.net/2268/170392

Ovidio M, Seredynski A, Philippart JC, Nzau Matondo B (2013) A bit of quiet between the migrations: the resting life of the European eel during their freshwater growth phase in a small stream. Aquat Ecol 47:291-301. doi:10.1007/s10452-0139444-1

Ovidio M, Tarrago-Bès F, Nzau Matondo B (2015) Short-term responses of glass eels transported from UK to small Belgian streams. Int J Lim. doi:10.1051/limn/2015016

Tesch FW (2003) The eel. J.E. Thorpe (ed.), 3rd edn. London: Blackwell Publishing, pp 408

van Ginneken VJT, Maes GE (2005) The European eel (Anguilla anguilla, Linnaeus), its lifecycle, evolution and reproduction: a literature review. Rev Fish Biol Fish 15:367-398. doi:10. 1007/s11160-006-0005-8

Welsh SA, Aldinger JL, Braham MA, Zimmerman JL (2015) Synergistic and singular effects of river discharge and lunar illumination on dam passage of upstream migrant yellowphase American eels. ICES J Mar Sci. doi:10.1093/icesjms/ fsv052

White EM, Knights B (1997) Environmental factors affecting migration of the European eel in the rivers Severn and Avon, England. J Fish Biol 50:1104-1116. doi:10.1111/j. 1095-8649.1997.tb01634.x 